\title{
Public health and regulation of the built environment
}

\section{Stephen J. Corbett}

Centre for Population Health, Sydney West Area Health Service Email:stephen_corbett@wsahs.nsw.gov.au

The earliest public health statutes contrived to develop effective controls of the excesses of the rapid urban development that accompanied the industrial revolution. By the end of the 20th century, much responsibility for the regulation of the built environment has been dispersed across government and in so doing has moved beyond the gaze of everyday public health concern. This paper argues firstly that there is a strong justification for greater public health involvement in the ongoing regulation of the built environment and secondly that a much broader range of health impacts needs to be considered in the conception of these regulatory measures.

The Health of Towns Association was formed in London in 1844 following the publication of Edwin Chadwick's Report on the Sanitary Conditions of the Labouring Population. ${ }^{1}$ The Association was an important lobby group which supported the sanitary reforms which culminated in the first Public Health Act of 1848, the direct progenitor of public health legislation in Australia. Its stated aim was to:

\footnotetext{
... substitute health for disease, cleanliness for filth, order for disorder, economy for waste, prevention for palliation, justice for charity, enlightened self-interest for ignorant selfishness, and to bring to the poorest and meanest - Air, Water, Light. ${ }^{2}$
}

Nineteenth century sanitary reforms created a durable system of governance of what at first was a narrow but pressing set of hazards in the built environment; local authorities were vested with responsibility for building standards and town planning, the control of noxious trades, water supply, sewage disposal, the management of burials and mortuaries and vermin control.

Over the last 150 years the public health infrastructure, especially in developed countries, has grown in both size and complexity. Some of the major components of this infrastructure, as it applies to the built environment, are summarised in Table 1. The evolution of this infrastructure is shaped by population growth, technological innovation, community expectations, environmental and resource constraints and importantly the national and international experience of regulatory and system failure, and disaster.

Responsibility for managing these hazards is now dispersed across government. ${ }^{3}$ Public health professionals have less involvement in the day-to-day management of these hazards than environmental scientists, traffic engineers, building-safety experts and professional urban planners. ${ }^{4}$ Regulatory oversight is similarly fragmented and in this situation it is easy for those working outside of the health system to lose sight of public health regulatory objectives.

There is however a strong justification for continued regulation of the built environment for public health, and for a more explicit role for public health agencies and professionals in defining or redefining public health objectives, in setting standards and in regulatory decision making. ${ }^{4}$ This role would or could include:

(a) An insistence on fidelity to the technical merits of policy proposals. ${ }^{5}$ Public health is not a self-evident virtue, and there is an active critique of the over-involvement of government in the everyday lives of citizens. At times there is a need to take a strong position, supported by evidence, to impose some controls on a new consumer product or to contest a policy proposal. By adherence to technical merits we mean a close examination of the feasibility, effectiveness and efficiency of proposed regulations. The recent technical and policy debate about the health effects of unflued gas heaters in Australian homes demonstrated the need for robust public health arguments to inform important decisions about energy use and sustainability. ${ }^{6}$

(b) Enabling the consideration of a much broader range of health impacts of urban planning, transport or building proposals. As Table 1 demonstrates, the regulatory framework for the built environment has been shaped largely by concerns about safety and injury prevention and communicable disease risk, and not by concerns about chronic disease prevention (cancer prevention and tobacco control are an exception). In many cases, these concerns can be addressed by an extension of current practice: for 
Table 1. Regulatory response and responsibility for hazards in the built environment

\begin{tabular}{|c|c|c|c|}
\hline \multirow[t]{2}{*}{ Hazard } & \multicolumn{2}{|c|}{ Public health infrastructure } & \multirow[t]{2}{*}{ Regulatory domain } \\
\hline & Policy and legislation & Physical Infrastructure & \\
\hline $\begin{array}{l}\text { Airborne infection } \\
\text { and overcrowding }\end{array}$ & $\begin{array}{l}\text { Tenancy laws } \\
\text { Fire safety codes } \\
\text { Floor space provision } \\
\text { Building codes } \\
\text { Ventilation standards }\end{array}$ & $\begin{array}{l}\text { Windows } \\
\text { Ceiling Heights }\end{array}$ & $\begin{array}{l}\text { Consumer protection } \\
\text { Fire Brigade } \\
\text { Public Health Act } \\
\text { Local government } \\
\text { Building Codes Board } \\
\text { Australian Standards }\end{array}$ \\
\hline Water borne diseases & $\begin{array}{l}\text { Drinking and waste-water } \\
\text { standards } \\
\text { Plumbing codes } \\
\text { Catchment protection }\end{array}$ & $\begin{array}{l}\text { Drinking and waste-water } \\
\text { infrastructure }\end{array}$ & $\begin{array}{l}\text { Catchment authorities } \\
\text { Water utilities } \\
\text { Water utilities }\end{array}$ \\
\hline Noise & Building codes & & Environment protection \\
\hline Chemical hazards & $\begin{array}{l}\text { Zoning laws } \\
\text { Product labelling and material } \\
\text { data safety sheets }\end{array}$ & Childproof containers & $\begin{array}{l}\text { Health and safety } \\
\text { Consumer protection } \\
\text { Dangerous goods }\end{array}$ \\
\hline $\begin{array}{l}\text { Crime and violence } \\
\text { prevention }\end{array}$ & & Street lighting & Urban planning \\
\hline Injury & & $\begin{array}{l}\text { Safety barriers } \\
\text { Road surfacing }\end{array}$ & Roads and transport \\
\hline Transport & Vehicle safety standards & & Roads and transport \\
\hline Insects and vermin & Building code & & Local government \\
\hline
\end{tabular}

Table 2. Examples of regulatory proposals directed at reducing risks of chronic disease

\begin{tabular}{|c|c|c|}
\hline Risk factors & Regulatory domain & Regulatory proposals \\
\hline \multirow[t]{4}{*}{$\begin{array}{l}\text { Obesity, physical activity } \\
\text { and nutrition }\end{array}$} & Land use planning & $\begin{array}{l}\text { Removal of provisions for the co-location of fuel and food } \\
\text { outlets, a convention which embeds car dependence for } \\
\text { even the shortest journeys }\end{array}$ \\
\hline & & $\begin{array}{l}\text { State Environment Planning Policy (SEPP) for walkability } \\
\text { in new developments }\end{array}$ \\
\hline & & $\begin{array}{l}\text { Making retail tenancy arrangements conducive to the } \\
\text { local availability of fresh food }\end{array}$ \\
\hline & Open space provision & $\begin{array}{l}\text { Codification of minimal open space quality and quantity } \\
\text { requirements for new developments }\end{array}$ \\
\hline \multirow[t]{3}{*}{ Noise } & Transport & Minimum setbacks from major roadways \\
\hline & & Adopting noise reducing technology for tyes and road surfacing \\
\hline & Building codes & Increasing noise mitigation specifications near busy roadways \\
\hline \multirow[t]{2}{*}{ Air quality } & Transport & Minimum setbacks from major roadways \\
\hline & Building codes & $\begin{array}{l}\text { Reduced indoor air pollutants specified in as the recently } \\
\text { introduced NSW Building Sustainability Index (BASIX) }\end{array}$ \\
\hline
\end{tabular}

example, while pedestrian safety will be a normal inclusion in any development proposal, explicit consideration of the extent to which a proposal encourages walking could easily be appended. ${ }^{4}$

(c) Proposing regulatory solutions to contemporary public health problems. The obesity epidemic and its links to sedentary lifestyles and, perhaps, to an urban form which predicates reductions in levels of physical activity have thrown open a debate about regulatory intervention for health in land use and urban planning. Prescriptive requirements for the location and number of fast food outlets and fresh food retailers and the mandating of urban residential densities have been proposed. A more promising 
approach may be an ongoing review of existing ordinances for pedestrian and cycling throughways, zoning, and lot size and layout. With this caveat in mind some examples of regulatory responses to contemporary public health responses are set out in Table 2.

(d) Being advocates and advisers in the public debates around climate change, sustainability and urban planning and the excesses of consumerism. The interactions between humans and their environment is complex and public health officials are well placed to provide a balanced perspective on acute and contingent health risks. Urban planning decisions in particular have the potential to shape ordinary lives over decades and the precautionary principle has special application to the health evidence used for or against specific proposals.

Our society has a vast fixed investment in public health infrastructure in the built environment: sewers, water treatment plants and storage facilities, road surfacing and engineering, public transport, building design and construction, consumer and product safety measures, fire prevention and waste disposal - all measures which underpin our health. In general these provisions do their work silently and are well accepted by the public. At the moment of their imposition there may be suspicion or alarm - there was a furious 20-year debate in Sydney about the building of the highly visible and ornate vents for Sydney's sewer system $^{7}$ - but, in time, if appropriate, these provisions will gain acceptance. The complexity of modern government should not deter public health officials from seeking out new regulatory approaches to the built environment for disease prevention.

\section{References}

1. Chadwick E. Report on the sanitary condition of the labouring population of Great Britain 1842. Edinburgh: Edinburgh University Press; 1965.

2. Centre for History in Public Health, London School of Hygiene and Tropical Medicine. Healthy Towns, Healthy Cities: Public Health in British Cities, 1844-2004. Conference Report. London: London School of Hygiene and Tropical Medicine; 2004. Available at: http://www.lshtm.ac.uk/ history/healthoftowns.html (Cited 11 September 2008.)

3. Giddens A. Risk - Hong Kong. 1999 Reith Lectures:Runaway World: BBC, 1999. Available at: http://www.bbc.co.uk/radio4/ reith1999/lecture2.shtml (Cited 11 September 2008.)

4. Perdue WC, Gostin LO, Stone LA. Public health and the built environment: historical, empirical and theoretical foundations for an expanded role. J Law Med Ethics 2003; 31: 557-66. doi:10.1111/j.1748-720X.2003.tb00123.x

5. Landy MK, Roberts MJ, Thomas SR. The Environment Protection Agency: asking the wrong questions from Nixon to Clinton. New York: Oxford University Press; 1994.

6. enHealth Council. The health effects of unflued gas heater use in Australia. Commonwealth of Australia, 2007. Available at: http://aodgp.gov.au/internet/main/publishing.nsf/Content/ ohp-enhealth-unflued-gas-heater-cnt.htm (Cited 11 September 2008.)

7. Beder S. From sewage farms to septic tanks: trials and tribulations in Sydney. J R Aust Hist Soc 1993; 79(1\&2): 72-95. 